\title{
ANALISIS OBYEK DAN KARAKTERISTIK DARI MATRIKS INDIKATOR MENGGUNAKAN HYBRID ANALISIS KELAS LATEN DENGAN BIPLOT ANALISIS KOMPONEN UTAMA (BIPLOT AKU)
}

\author{
Irlandia Ginanjar, Anindya Apriliyanti Pravitasari, Aleknaek Martuah \\ Jurusan Statistika, Universitas Padjadjaran, Bandung \\ email: irlandia_g@unpad.ac.id
}

\begin{abstract}
Analysis of the object and the characteristics will be much easier, efficient, and informative when based on a perceptual map, which can display objects and characteristics. Indicator matrix is a matrix where the rows represent objects and the columns is a dummy variable representing characteristics. This article writes about techniques to make perceptual map from indicator matrix, where that can provide information about the similarity between objects, the diversity of each characteristic, correlations between the characteristics, and characteristic values for each object, the techniques we call Hybrid Latent Class Cluster with PCA Biplot, where Latent Class Cluster Analysis is used to transform the indicator matrix to cross section matrix, where rows represent the objects and columns represent the characteristics, the observation cells is the probability of characteristic for each object, next the cross section matrix mapped using Principal Component Analysis Biplot (PCA Biplot).
\end{abstract}

Key Words: Hybrid Latent Class Cluster with PCA Biplot, Latent Class Cluster Analysis, Biplot Principal Component Analysis, Indicator Matrix.

\section{Pendahuluan}

Analisis obyek dan karakteristik akan lebih mudah, efisien dan informatif bila berdasarkan pada peta persepsi yang dapat menampilkan obyek dan karakteristik. Berbagai metoda statistika yang bisa digunakan untuk pemetaan adalah multidimensional scaling $(\mathrm{MDS})^{[9]}$, individual difference scaling (INDSCAL) ${ }^{[8]}$, Parallel factor analysis $(\text { PARAFAC })^{[7]}$, general procrustean analysis $(\mathrm{GPA})^{[11]}$, analisis Biplot Analisis Komponen Utama (Biplot AKU) ${ }^{[2]}$, DISTATIS ${ }^{1]}$, Hybrid DISTATIS ${ }^{[3]}$, dan Hybrid Korespondensi dengan Biplot $\mathrm{AKU}^{[4]}$, namun berbagai metoda statistika tersebut tidak dapat digunakan jika data berbentuk matriks indikator.

Matriks indikator adalah matriks dimana baris mewakili obyek dan kolom merupakan variabel dummy yang mewakili karakteristik ${ }^{[10]}$. Peta presepsi dari data berbentuk matriks indikator hanya dapat dibangun menggunakan Multiple Correspondence Analysis (MCA) ${ }^{[5]}$ melalui matriks Burt tapi kekurangannya adalah informasi tentang obyek hilang, karena data obyek dikumpulkan untuk mendapatkan matriks Burt, akibatnya informasi tentang kesamaan antar obyek dan nilai karakteristik untuk setiap obyek tersembunyi, selain itu juga metoda ini tidak memberikan informasi keragaman setiap karakteristik.

Berdasarkan hal itu kami memperkenalkan Hybrid Analisis Kelas Laten dengan Biplot AKU, dimana Analisis Kelas Laten ${ }^{[6]}$ digunakan untuk mentransformasi matriks indikator ke matriks cross section, dengan baris mewakili obyek dan kolom mewakili karakteristik dengan sel pengamatan merupakan peluang karakteristik untuk setiap obyek, selanjutnya matriks baris kolom dipetakan menggunakan Biplot AKU.

Berdasarkan hal di atas, maka tujuan yang ingin dicapai dalam penelitian ini adalah 
(1) Mentransformasi matriks indikator ke matriks cross section menggunakan Analisis Kelas Laten Hirarki

(2) Memetakan matriks cross section menggunakan Biplot AKU

(3) Mengidentifikasi informasi kemiripan antar obyek, keragaman setiap karakteristik, korelasi antar karakteristik, dan kepemilikan karakteristik untuk setiap obyek dari peta Hybrid Analisis Kelas Laten dengan Biplot AKU.

\section{Metode}

Berdasarkan tujuan makalah ini maka analisis data dilakukan mulai dari mentransformasi matriks indikator ke matriks cross section dengan menggunakan Analisis Kelas Laten, kedua adalah menghitung titik koordinat dengan menggunakan Biplot AKU, sehingga didapatkan peta dua dimensi, dan selanjutnya mengidentifikasi informasi dari peta yang dihasilkan. Langkahlangkah penelitian yang dilakukan digambarkan dalam bentuk diagram alur analisis data yang disajikan di Gambar 1.

Pada prinsipnya dari metoda Analisis Kelas Laten akan menghasikan matriks cross section yang merupakan peluang karakteristik untuk setiap kelompok Obyek. Matriks matriks cross section dianalisis dengan menggunakan metoda Biplot AKU untuk mendapatkan matriks efek baris dan kolom.

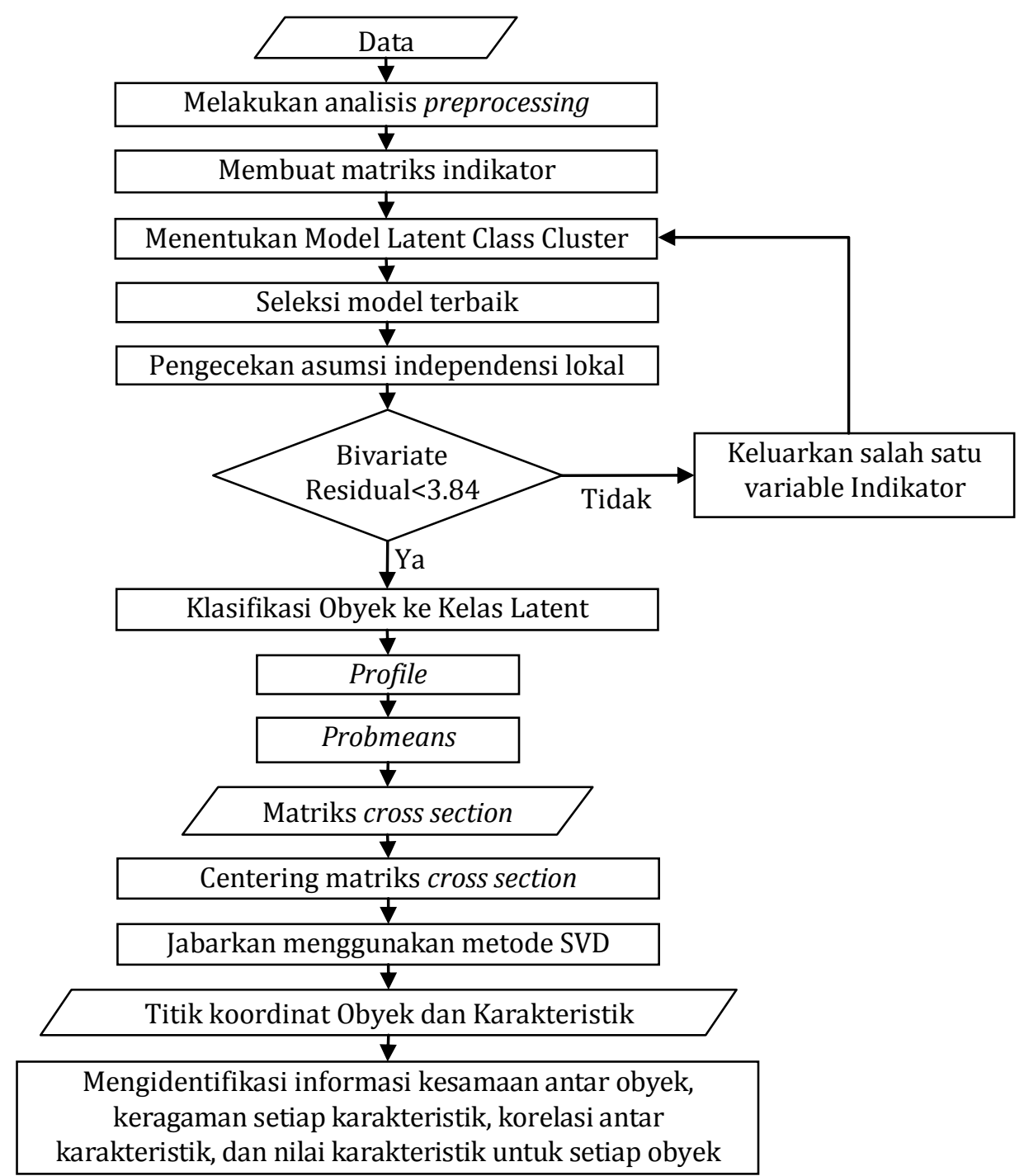

Gambar 1. Diagram Alur Analisis Data. 
Titik koordinat obyek didapatkan dari dua kolom pertama matriks efek baris, dan titik koordinat karakteristik didapatkan dari dua kolom pertama matriks efek kolom. Titik koordinat obyek dan karakteristik dipetakan dalam satu peta yang sama, dimana obyek sedangkan karakteristik berbentuk vektor.

\section{Hasil dan Pembahasan}

\subsection{Sumber Data Penelitian}

Dalam penelitian ini, data yang digunakan adalah berupa data sekunder yang diperoleh dari peneliti di bidang pemuliaan tanaman di Balai Penelitian Tanaman Sayuran. Terdapat 26 genotipe dari tanaman terung, dengan 14 variabel yang direkomendasikan oleh Pusat Perlindungan Varietas Tanaman pada Panduan Individual Kebaruan, Keunikan, Keseragaman dan Kestabilan. Struktur data secara lengkap disajikan pada Lampiran 1.

\subsection{Pembentukan Matriks Indikator}

Sebelum dilakukan analisis menggunakan Hybrid Analisis Kelas Laten dengan Biplot AKU, data spesies terung yang terdiri dari 26 Obyek dengan 14 karakteristik dibentuk kedalam matriks indikator. Matriks indikator berisikan angka nol atau satu, berisikan satu jika obyek tergolong pada suatu kategori pada variabel tertentu, dan sebaliknya berisikan nol jika tidak tergolong pada kategori tersebut. Matriks indikator yang terbentuk dapat dilihat pada Lampiran 2.

\subsection{Analisis Kelas Laten untuk Mendapatkan Nilai Profile}

Matriks indikator yang telah terbentuk merupakan inputan untuk pengolahan data menggunakan Analisis Kelas Laten Hirarki. Pada penelitian ini, dilakukan pengelompokkan sesuai dengan banyaknya obyek (26 kelompok). Hal ini dilakukan agar pembentukan biplot AKU menghasilkan visualisasi dan informasi yang baik.

Pembentukan model latent class, harus memenuhi asumsi independensi lokal yang dinyatakan oleh nilai bivariate residual $<3,84^{[12]}$. Dari 49 indikator, 17 diantaranya memiliki asosiasi dengan indikator lainnya dengan nilai bivariat residual yang besar (analisis awal) sehingga asumsi independensi lokal tidak terpenuhi. Untuk mengatasi hal ini, biasanya dilakukan penembahan jumlah klaster laten atau menambahkan efek langsung (direct effect) pada 2 variabel yang memiliki nilai bivariat residual yang besar. Namun untuk mempertahankan jumlah klaster sebanyak 5 klaster maka ketujuh belas indikator yang menimbulkan nilai bivariat yang besar dikeluarkan dari model. Asumsi independensi lokal untuk pengelompokkan obyek kedalam 26 klaster terpenuhi untuk 32 variabel, dengan hasil pengelompokkan terdapat pada Tabel 1. Nilai Profile yang menyertakan tiap anggota klaster yang terdapat pada Tabel 1.

\subsection{Pembentukan matriks Cross Section.}

Pembentukan matriks cross section didasarkan pada nilai Profile yang dihasilkan oleh metoda Analisis Kelas Laten. Variabel yang mempunyai nilai Profile Nol semua berarti seluruh obyek tidak memiliki kategori karakteristik tersebut, maka variabel tersebut tidak disertakan dalam matriks cross section.

Nilai Profile menyertakan nilai peluang obyek memiliki kategori karakteristik atau tidak (lawan kata, dalam kasus ini terdapat peluang untuk "ada" dan "tidak ada", atau peluang untuk "ya" dan "tidak"), dimana jumlah peluang suatu obyek memiliki kategori karakteristik dengan tidak memiliki kategori karakteristik sama dengan 1 (satu), sehingga data yang digunakan untuk membentuk matriks cross section adalah nilai peluang suatu obyek memiliki kategori 
karakteristik tersebut. Matriks cross section yang akan digunakan untuk analisis lanjut dapat dilihat pada Lampiran 3.

Tabel 1. Anggota Klaster Laten untuk 26 Klaster

\begin{tabular}{lcl}
\hline Klaster & Jumlah obyek & \multicolumn{1}{c}{ Obyek } \\
\hline Klaster 1 & 4 & Or Plane, Gelatik, Green Ta, Kenari \\
Klaster 2 & 4 & B 19, Bungo, Lezata, Texas \\
Klaster 3 & 3 & B 27, Mustang, Or valer \\
Klaster 4 & 3 & Rami, Antaboga, Lanang J \\
Klaster 5 & 2 & Hape, Or Fabia \\
Klaster 6 & 1 & Ratih Un \\
Klaster 7 & 1 & Patriot \\
Klaster 8 & 1 & B 47 \\
Klaster 9 & 1 & Hijo \\
Klaster 10 & 1 & Pondoh \\
Klaster 11 & 1 & Bimbi \\
Klaster 12 & 1 & Ratih Hi \\
Klaster 13 & 1 & Fortuna \\
Klaster 14 & 1 & Kera Put \\
Klaster 15 & 1 & Fullness \\
Klaster 16 & 0 & - \\
Klaster 17 & 0 & - \\
Klaster 18 & 0 & - \\
Klaster 19 & 0 & - \\
Klaster 20 & 0 & - \\
Klaster 21 & 0 & - \\
Klaster 22 & 0 & - \\
Klaster 23 & 0 & - \\
Klaster 24 & 0 & - \\
Klaster 25 & 0 & - \\
Klaster 26 & 0 & - \\
\hline Jumlah & 26 & \\
\hline
\end{tabular}

\subsection{Biplot Analisis Komponen Utama (Biplot AKU) untuk Memetakan Obyek dan Kategori Kolom berdasarkan Matriks Cross Section}

Matriks cross section merupakan data inputan untuk Biplot AKU. Biplot AKU menghasilkan Titik koordinat Obyek dan titik koordinat kolom hasil lainnya yang berguna untuk pemetaan yaitu persentase keragaman (inertia) yang merupakan nilai indikator kualitas pemetaan.

Posisi obyek pada peta yang dihasilkan memberikan cara yang lebih mudah untuk menginterpretasikan kemiripan antar obyek. Semakin dekat jarak antar obyek maka obyek tersebut semakin mirip, semakin jauh jarak antar titik maka semakin berbeda. Posisi obyek tersebut juga dapat digunakan untuk mengelompokan obyek secara visual, dengan semakin dekat jarak titik antar obyek maka dapat dikelompokan, semakin jauh jarak titik antar obyek maka tidak dapat dikelompokan.

Panjang vektor (garis yang mempunyai arah) karakteristik yang pada peta yang dihasilkan memberikan cara yang lebih mudah untuk menginterpretasikan keragaman setiap karakteristik. Semakin panjang vektor karakteristik tersebut maka keragaman karakteristik tersebut semakin besar, Semakin pendek vektor karakteristik tersebut maka keragaman karakteristik tersebut kecil.

Korelasi antar karakteristik diidentifikasi berdasarkan sudut antar vektor karakteristik. Jika sudut antar vektor karakteristik mendekati $0^{\circ}$ atau $360^{\circ}$ (dua vektor karakteristik berhimpit) maka dua vektor tersebut memiliki korelasi positif yang sangat erat, jika sudut antar vektor karakteristik mendekati $180^{\circ}$ (dua vektor karakteristik mempunyai arah berlawanan) maka dua 
vektor tersebut memiliki korelasi negatif yang sangat erat, jika sudut antar vektor karakteristik mendekati $90^{\circ}$ atau $270^{\circ}$ (dua vektor karakteristik obyek saling tegak lurus) maka vektor tersebut tidak berkorelasi.

Kepemilikan karakteristik untuk setiap obyek diidentifikasi berdasarkan posisi obyek terhadap arah vektor karakteristik. Jika vektor karakteristik semakin mengarah kepada posisi obyek maka obyek tersebut semakin dapat dipastikan memiliki karakteristik tersebut, jika vektor karakteristik mempunyai arah yang semakin menjauhi obyek maka obyek tersebut semakin dapat dipastikan tidak memiliki karakteristik tersebut.

Komulatif persentase keragaman dua dimensi dari data yang digunakan dalam penlitian ini didapatkan sebesar 69,55\%, maka peta dua dimensi yang dihasilkan mengcover 69,55\% keragaman data sebenarnya, berdasarkan hal itu peta dua dimensi yang dihasilkan cukup baik untuk digunakan sebagai dasar pengambilan keputusan. Persentase keragaman, Titik koordinat untuk 26 obyek yang di obervasi, dan Titik koordinat untuk pemetaan 20 vektor karakteristik, disajikan pada Tabel 2 .

Titik koordinat Obyek dan titik koordinat vektor karakteristik dipetakan, sehingga didapatkan peta dua dimensi obyek, dan vektor karakteristik obyek, hasil dari metoda Biplot AKU dengan inputan matriks cross section yang merupakan output Analisis Kelas Laten, dimana imputan Analisis Kelas Laten adalah matriks indikator yang kami namakan dengan Hybrid Analisis Kelas Laten dengan Biplot AKU, dengan peta yang dihasilkan disajikan di Gambar 2.

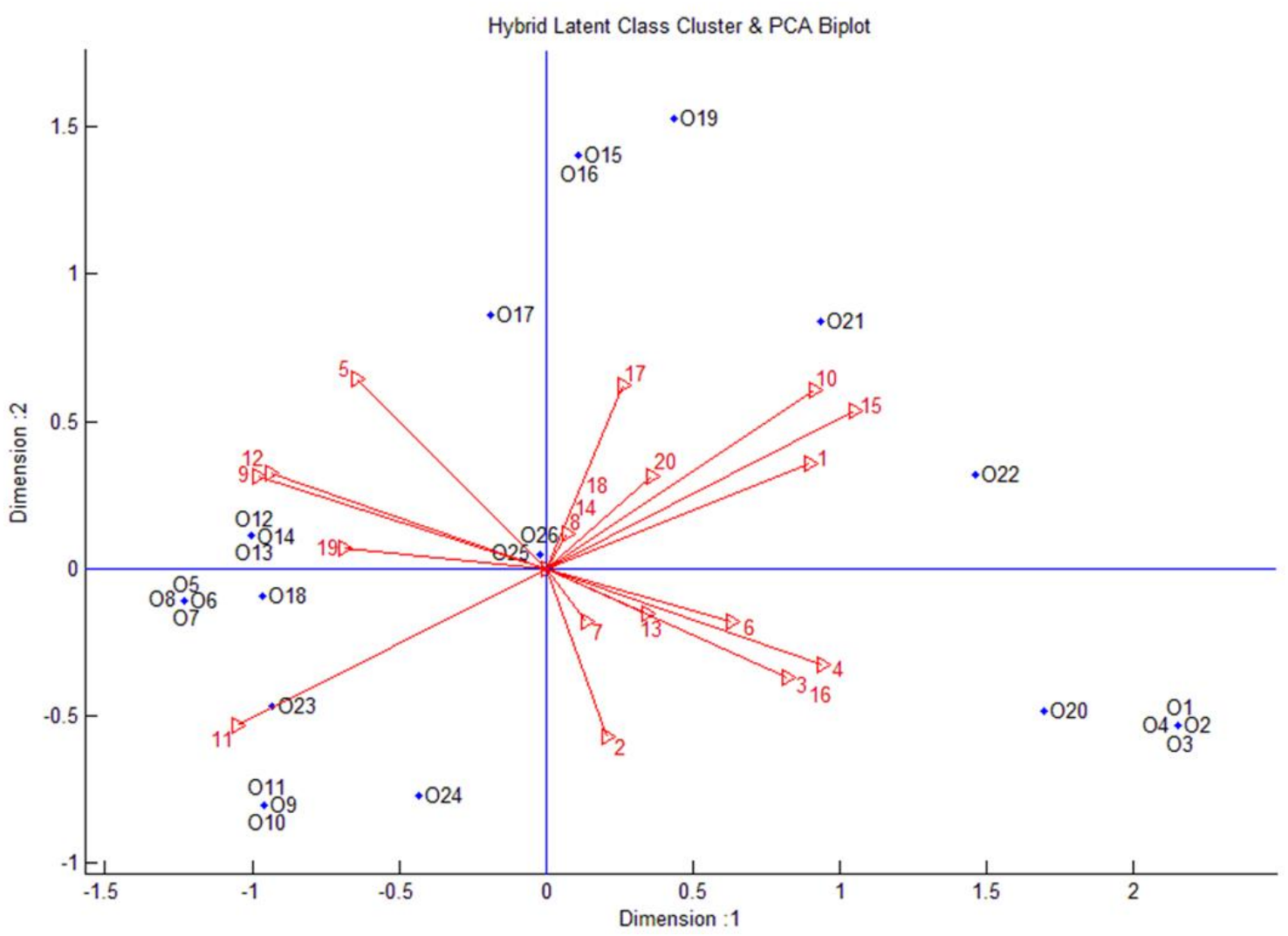

Gambar 2. Diagram Hasil dari Metoda Hybrid Analisis Kelas Laten dengan Biplot AKU 
Tabel 2. Persen Keragaman (Inersia) dan Titik Koordinat 26 Varietas dan Titik Koordinat 20 Karakteristik.

\begin{tabular}{|c|c|c|c|}
\hline \multicolumn{2}{|l|}{ Dimensi } & 1 & 2 \\
\hline \multicolumn{2}{|c|}{ Persen Keragaman } & 52,93 & 16,62 \\
\hline \multirow{26}{*}{ Varietas } & 1. Or Plane & 2,1537 & $-0,5346$ \\
\hline & 2. Gelatik & 2,1537 & $-0,5346$ \\
\hline & 3. Green Ta & 2,1537 & $-0,5346$ \\
\hline & 4. Kenari & 2,1537 & $-0,5346$ \\
\hline & 5. B19 & $-1,2318$ & $-0,1084$ \\
\hline & 6. Bungo & $-1,2318$ & $-0,1084$ \\
\hline & 7. Lezata & $-1,2318$ & $-0,1084$ \\
\hline & 8. Texas & $-1,2318$ & $-0,1084$ \\
\hline & 9. B27 & $-0,9574$ & $-0,8034$ \\
\hline & 10. Mustang & $-0,9574$ & $-0,8034$ \\
\hline & 11. Or Valer & $-0,9574$ & $-0,8034$ \\
\hline & 12. Rami & $-1,0031$ & 0,1133 \\
\hline & 13. Antaboga & $-1,0031$ & 0,1133 \\
\hline & 14. Lanang J & $-1,0031$ & 0,1133 \\
\hline & 15. Hape & 0,1085 & 1,4072 \\
\hline & 16. Or Fabia & 0,1085 & 1,4072 \\
\hline & 17. Ratih Un & $-0,1877$ & 0,8618 \\
\hline & 18. Patriot & $-0,9633$ & $-0,0933$ \\
\hline & 19. B47 & 0,4381 & 1,5323 \\
\hline & 20. Hijo & 1,6943 & $-0,4882$ \\
\hline & 21. Pondoh & 0,9388 & 0,8423 \\
\hline & 22. Bimbi & 1,4622 & 0,3203 \\
\hline & 23. Ratih Hi & $-0,9317$ & $-0,4690$ \\
\hline & 24. Fortuna & $-0,4315$ & $-0,7722$ \\
\hline & 25. Kera Put & $-0,0209$ & 0,0469 \\
\hline & 26. Fullness & $-0,0209$ & 0,0469 \\
\hline \multirow{20}{*}{ Karakteristik } & 1. Ada Warna Antosianin & 0,8991 & 0,3582 \\
\hline & 2. Tipe Tumbuh Tegak & 0,2064 & $-0,5737$ \\
\hline & 3. Ada Intensitas Antosianin & 0,8243 & $-0,3718$ \\
\hline & 4. Panjang Buah Sangat Pendek & 0,9399 & $-0,3260$ \\
\hline & 5. Ratio Panjang Per Diameter Sedang & $-0,6444$ & 0,6429 \\
\hline & 6. Bentuk Umum Buah Bundar & 0,6334 & $-0,1819$ \\
\hline & 7. Bentuk Umum Buah Blat Telur & 0,1391 & $-0,1825$ \\
\hline & 8. Bentuk Umum Buah Bentuk Pir & 0,0742 & 0,1194 \\
\hline & 9. Bentuk Umum Buah Silindris & $-0,9804$ & 0,3132 \\
\hline & 10. Warna Buah Masak Panen Hijau & 0,9167 & 0,6044 \\
\hline & 11. Warna Buah Masak Panen Ungu & $-1,0505$ & $-0,5361$ \\
\hline & 12. Ada Garis Buah & $-0,9399$ & 0,3260 \\
\hline & 13. Tulang Buah Lemah & 0,3452 & $-0,1518$ \\
\hline & 14. Tulang Buah Sedang & 0,0742 & 0,1194 \\
\hline & 15. Ada Antosianin Bawah Kelopak Bunga & 1,0505 & 0,5361 \\
\hline & 16. Intensitas Antosianin Kelopak Bunga Sangat Lemah & 0,8243 & $-0,3718$ \\
\hline & 17. Kerutan Kelopak Bunga Sedang & 0,2638 & 0,6252 \\
\hline & 18. Kerutan Kelopak Bunga Sangat Kuat & 0,0742 & 0,1194 \\
\hline & 19. Waktu Mulai Pembungaan Sedang & $-0,6883$ & 0,0693 \\
\hline & 20. Waktu Mulai Pembungaan Akhir & 0,3581 & 0,3137 \\
\hline
\end{tabular}

Berdasarkan Gambar 2, terlihat bahwa Posisi Obyek 1, 2, 3, dan 4 (Or Plane, Gelatik, Green Ta, dan Kenari) berhimpit dekat dengan Obyek 20 (Hijo), hal itu memberikan informasi bahwa keempat obyek tersebut sangat mirip dan relatif mirip dengan Obyek 20. Posisi Obyek 12, 13, dan 14 (Rami, Antaboga, dan Lanang J) sangat jauh dibandingkan dengan pasisi Obyek 1, 2, 3, dan 4, hal itu memberikan informasi bahwa Obyek 1, 2, 3, dan 4 sangat berbeda dengan Posisi Obyek 12, 13, dan 14. 
Berdasarkan posisi obyek itu juga kita dapat lihat bahwa Obyek 5, 6, 7, 8, 12, 13, 14, dan 18 mempunyai posisi yang saling berdekatan, sehingga delapan obyek tersebut dapat digabung kedalam kelompok yang sama.

Vektor karakteristik 4 (panjang buah sangat pendek) mempunyai garis yang panjang, hal itu memberikan informasi bahwa panjang buah dari 26 varietas tersebut relatif berbeda-beda. Vektor karakteristik 7 (buah berbentuk bulat telur) mempuyai garis yang pendek, hal itu memberikan informasi bahwa bentuk buah dari 26 varietas tersebut relatif sama.

Vektor karakteristik 4 (panjang buah sangat pendek) dengan Vektor karakteristik 6 (bentuk umum buah bundar) berhimpit, hal itu memberikan informasi bahwa kedua vektor karakteristik tersebut berkorelasi positif sangat erat. Vektor karakteristik 4 dengan Vektor karakteristik 17 (kerutan kelopak bunga sedang) tegak lurus, hal itu memberikan informasi bahwa kedua vektor karakteristik tersebut tidak berkorelasi. Vektor karakteristik 4 dengan Vektor karakteristik 9 (bentuk umum buah silindris) berlawanan arah, hal itu memberikan informasi bahwa kedua vektor karakteristik tersebut berkorelasi negatif sangat erat.

Vektor karakteristik 4, 6, 3, 16, dan 13 (panjang buah sangat pendek, bentuk umum buah bundar, ada intensitas antosianin, intensitas antosianin kelopak bunga sangat lemah, dan tulang buah lemah) terlihat mengarah ke Obyek 1, 2, 3, dan 4, maka semakin dapat dipastikan bahwa Or Plane, Gelatik, Green Ta, dan Kenari memiliki karakteristik panjang buah sangat pendek, bentuk umum buah bundar, ada intensitas antosianin, intensitas antosianin kelopak bunga sangat lemah, dan tulang buah lemah. Vektor karakteristik 19, 9, dan 12 (waktu mulai pembungaan sedang, bentuk umum buah silindris, dan ada garis buah) terlihat mengarah ke Obyek 12, 13, dan 14, maka semakin dapat dipastikan bahwa Rami, Antaboga, dan Lanang J memiliki karakteristik waktu mulai pembungaan sedang, bentuk umum buah silindris, dan ada garis buah.

\section{Kesimpulan dan Saran}

\subsection{Kesimpulan}

Hybrid Analisis Kelas Laten dengan Biplot AKU dapat menghasilkan peta presepsi dari data berbentuk matriks indikator yang dapat memberikan informasi tentang kesamaan antar obyek, keragaman setiap karakteristik, korelasi antar karakteristik, dan kepemilikan karakteristik untuk setiap obyek. Metoda Hybrid Analisis Kelas Laten dengan Biplot AKU adalah penggabungan dari dua metoda dimana Analisis Kelas Laten digunakan untuk mentransformasi matriks indikator ke matriks cross section, dimana baris mewakili obyek dan kolom mewakili karakteristik dengan sel pengamatan merupakan peluang karakteristik untuk setiap obyek, selanjutnya matriks cross section yang didapatkan dipetakan menggunakan Biplot AKU.

Pembentukan matriks cross section didasarkan pada nilai Profile yang dihasilkan oleh metoda Analisis Kelas Laten. Variabel yang mempunyai nilai Profile Nol semua berarti seluruh obyek tidak memiliki kategori karakteristik tersebut, maka variabel tersebut tidak disertakan dalam matriks cross section. Nilai Profile menyertakan nilai peluang obyek memiliki kategori karakteristik atau tidak, dimana jumlah peluang memiliki kategori karakteristik dan tidak sama dengan 1 (satu), sehingga data yang digunakan untuk membentuk matriks cross section adalah nilai peluang suatu obyek memiliki kategori karakteristik.

Persentase kualitas pemetaan Metoda Hybrid Analisis Kelas Laten dengan Biplot AKU dalam dua dimensi dapat diidentifikasi berdasarkan komulatif dari persentase keragaman pertama dan kedua. Posisi obyek pada peta yang dihasilkan memberikan cara yang lebih mudah untuk menginterpretasikan kemiripan antar obyek. Panjang vektor (garis 
yang mempunyai arah) karakteristik yang pada peta yang dihasilkan memberikan cara yang lebih mudah untuk menginterpretasikan keragaman setiap karakteristik. Korelasi antar karakteristik diidentifikasi berdasarkan sudut antar vektor karakteristik. Kepemilikan karakteristik untuk setiap obyek diidentifikasi berdasarkan posisi obyek terhadap arah vektor karakteristik.

\subsection{Saran}

1. Jika data berasal dari sampel dan hasil analisis yang diinginkan dapat mempresentasikan populasi maka harus menggunakan teknik pengambilan sampel peluang (Probability sampling).

2. Mencari metoda Analisis Kelas Laten yang paling cocok untuk Metoda Hybrid Analisis Kelas Laten dengan Biplot AKU, sementara itu dalam penelitian ini menggunakan metoda Analisis Kelas Laten Hirarki.

\section{DAFTAR PUSTAKA}

1. Abdi, H., and Valentin, D., DISTATIS, Encyclopedia of Measurement and Statistics, Ed: Salkind, N., Sage Publications, Inc., 2007, California, hal. 284-291.

2. Gabriel, K.R., The Biplot Graphic Display of Matrices with Application to Principal Component Analysis, Biometrika, 1971, Vol. 58, No. 3, hal. 453-467.

3. Ginanjar, I., Analisis Produk dan Assessor dari Data Penyortiran menggunakan Hybrid DISTATIS, Prosiding Seminar Nasional Statistika, Universitas Diponegoro, 2011a, ISBN: 978-979-097-142-4, hal. 25-37.

4. Ginanjar, I., Hybrid Korespondensi untuk Menganalisis Obyek Berdasarkan Kategori Kolom dan Karakteristik Obyek, Prosiding Seminar Nasional Statistika, Universitas Padjadjaran, 2011b, ISBN: 2087-5290, hal. 303-313.

5. Greenacre, M.J., and Blasius, J., Multiple Correspondence Analysis and Related Methods, Taylor and Francis Group, LLC, Boca Raton, Florida, 2006.

6. Hagenaars, J.A., Mc.Cutcheon, Applied Latent Class Analysis, Cambridge University: USA, 2002.

7. Harshman, R.A., and Lundy, M.E., PARAFAC: Parallel Factor Analysis, Computational Statistics and Data Analysis, 1994, Vol. 18, hal. 39-72.

8. Husson, F., and Pagès, J., INDSCAL Model: Geometrical Interpretation and Methodology, Computational Statistics and Data Analysis, 2006, Vol. 50, hal. 358378.

9. Kruskal, J., and Wish, M., Multidimensional Scaling, Sage University Papers Series. Quantitative Applications in the Social Sciences, 1978, No. 07-011, Sage Publications, Inc., Iowa.

10. Le Roux, B., and Rouanet, H., Geometric Data Analysis, from Correspondence Analysis to Structured Data Analysis, Dordrecht, Kluwer, 2004, p.179

11. Meyners, M., Kunert, J., and Qanari E.M., "Comparing Generalized Procrustes Analysis and Statis", Food Quality and Preference, 2000, Vol. 11, hal. 77-83.

12. Vermunt,J.K. and Magidson, J., Latent Class Models. Tilburg University, Statistical Innovations Inc., 2003. 
Lampiran 1. Struktur Data Penelitian

\begin{tabular}{|c|c|c|c|}
\hline No & Variabel & Keterangan & Kategori \\
\hline 1. & X1-2 & $\begin{array}{l}\text { Kecambah: } \\
\text { Intensitas } \\
\text { Pewarnaan } \\
\text { antosianin } \\
\text { pada Hipokotil }\end{array}$ & $\begin{array}{l}\text { a. Tidak Ada } \\
\text { b. Sangat Lemah } \\
\text { c. Lemah } \\
\text { d. Sedang } \\
\text { e. Kuat } \\
\text { f. Sangat Kuat }\end{array}$ \\
\hline 2. & X3 & $\begin{array}{l}\text { Tanaman: } \\
\text { Tipe Tumbuh }\end{array}$ & $\begin{array}{l}\text { a. Tegak } \\
\text { b. Semi Tegak } \\
\text { c. Horisontal }\end{array}$ \\
\hline 3 & X6-7 & $\begin{array}{l}\text { Batang: } \\
\text { Intensitas } \\
\text { Pewarnaab } \\
\text { antosianin }\end{array}$ & $\begin{array}{l}\text { a. Tidak Ada } \\
\text { b. Sangat Lemah } \\
\text { c. Lemah } \\
\text { d. Sedang } \\
\text { e. Kuat } \\
\text { f. Sangat Kuat }\end{array}$ \\
\hline 4 & $\mathrm{X} 17$ & Buah: Panjang & $\begin{array}{l}\text { a. Sangat Pendek } \\
\text { b. Pendek } \\
\text { c. Sedang } \\
\text { d. Panjang } \\
\text { e. Sangat Panjang }\end{array}$ \\
\hline 5 & X19 & $\begin{array}{l}\text { Buah: Ratio } \\
\text { Panjang/ } \\
\text { Diameter }\end{array}$ & $\begin{array}{l}\text { a. Sangat Kecil } \\
\text { b. Kecil } \\
\text { c. Sedang } \\
\text { d. Besar } \\
\text { e. Sangat Besar }\end{array}$ \\
\hline 6 & $\mathrm{X} 22$ & $\begin{array}{l}\text { Buah: Bentuk } \\
\text { Umum }\end{array}$ & $\begin{array}{l}\text { a. Bundar } \\
\text { b. Bulat Telur } \\
\text { c. Bulat Telur Sungsang } \\
\text { d. Bentuk Pir } \\
\text { e. Bentuk Club } \\
\text { f. Jorong } \\
\text { g. Silindris }\end{array}$ \\
\hline 7 & $\mathrm{X} 25$ & $\begin{array}{l}\text { Buah: Warna } \\
\text { Masak Buah }\end{array}$ & $\begin{array}{ll}\text { a. } & \text { Putih } \\
\text { b. } & \text { Hijau } \\
\text { c. } & \text { Ungu } \\
\text { d. } & \text { Kuning } \\
\end{array}$ \\
\hline
\end{tabular}

\begin{tabular}{|c|c|c|c|}
\hline No & Variabel & Keterangan & Kategori \\
\hline 8 & $\mathrm{X} 29$ & $\begin{array}{l}\text { Buah: Garis- } \\
\text { garis }\end{array}$ & $\begin{array}{l}\text { a. Tidak Ada } \\
\text { b. Ada }\end{array}$ \\
\hline 9 & X32 & Buah: Tulang & $\begin{array}{l}\text { a. Sangat Lemah } \\
\text { b. Lemah } \\
\text { c. Sedang } \\
\text { d. Kuat } \\
\text { e. Sangat Kuat }\end{array}$ \\
\hline 10 & X34 & $\begin{array}{l}\text { Buah: Intensitas } \\
\text { Pewarnaan } \\
\text { Antosianin di } \\
\text { bawah Kelopak } \\
\text { Bunga }\end{array}$ & $\begin{array}{ll}\text { a. } & \text { Tidak Ada } \\
\text { b. Lemah } \\
\text { c. Sedang } \\
\text { d. Kuat }\end{array}$ \\
\hline 11 & X38 & $\begin{array}{l}\text { Buah: Intensitas } \\
\text { Pewarnaan } \\
\text { Antosianin pada } \\
\text { Kelopak Bunga }\end{array}$ & $\begin{array}{l}\text { a. Tidak Ada } \\
\text { b. Sangat Lemah } \\
\text { c. Lemah } \\
\text { d. Sedang } \\
\text { e. Kuat } \\
\text { f. Sangat Kuat }\end{array}$ \\
\hline 12 & $\mathrm{X} 40$ & $\begin{array}{l}\text { Buah: Kerutan } \\
\text { Kelopak Bunga }\end{array}$ & $\begin{array}{l}\text { a. Sangat Lemah } \\
\text { b. Lemah } \\
\text { c. Sedang } \\
\text { d. Kuat } \\
\text { e. Sangat Kuat }\end{array}$ \\
\hline 13 & $\mathrm{X} 42$ & $\begin{array}{l}\text { Buah: Warna } \\
\text { Daging Buah }\end{array}$ & $\begin{array}{ll}\text { a. Keputih-putihan } \\
\text { b. Kehijau-hijauan }\end{array}$ \\
\hline 14 & $\mathrm{X} 44$ & $\begin{array}{l}\text { Waktu Awal } \\
\text { Pembungaan }\end{array}$ & $\begin{array}{ll}\text { a. } & \text { Awal } \\
\text { b. Sedang } \\
\text { c. } & \text { Akhir }\end{array}$ \\
\hline
\end{tabular}


Media Statistika, Vol. 6, No. 2, Desember 2013:91-101

Lampiran 2. Matriks Indikator

\begin{tabular}{|c|c|c|c|c|c|c|c|c|c|c|c|c|c|c|c|c|}
\hline VARIETAS & $\mathrm{X} 1 \mathrm{~A}$ & $\mathrm{X} 1 \mathrm{~A}^{\mathrm{c}}$ & $\mathrm{X} 3 \mathrm{~A}$ & X3B & $\mathrm{X} 3 \mathrm{C}$ & $\mathrm{X} 6 \mathrm{~A}$ & $\mathrm{X} 6 \mathrm{~A}^{\mathrm{c}}$ & $\mathrm{X} 17 \mathrm{~A}$ & X17B & X17C & X17D & X17E & $\mathrm{X} 19 \mathrm{~A}$ & X19B & X19C & X19D \\
\hline Antaboga-1 & 0 & 1 & 0 & 1 & 0 & 0 & 1 & 0 & 0 & 0 & 1 & 0 & 0 & 0 & 1 & 0 \\
\hline lanang jagad & 0 & 1 & 0 & 1 & 0 & 0 & 1 & 0 & 0 & 1 & 0 & 0 & 0 & 1 & 0 & 0 \\
\hline Texas & 0 & 1 & 0 & 1 & 0 & 0 & 1 & 0 & 0 & 1 & 0 & 0 & 0 & 0 & 1 & 0 \\
\hline Bimbi & 0 & 1 & 1 & 0 & 0 & 0 & 1 & 0 & 0 & 1 & 0 & 0 & 0 & 0 & 1 & 0 \\
\hline Rami & 0 & 1 & 0 & 1 & 0 & 0 & 1 & 0 & 0 & 1 & 0 & 0 & 0 & 0 & 1 & 0 \\
\hline B-47 & 1 & 0 & 0 & 0 & 1 & 1 & 0 & 1 & 0 & 0 & 0 & 0 & 0 & 1 & 0 & 0 \\
\hline Hijo & 1 & 0 & 0 & 1 & 0 & 0 & 1 & 0 & 0 & 1 & 0 & 0 & 0 & 1 & 0 & 0 \\
\hline Hape & 1 & 0 & 0 & 1 & 0 & 0 & 1 & 0 & 0 & 1 & 0 & 0 & 0 & 0 & 1 & 0 \\
\hline Patriot & 1 & 0 & 0 & 1 & 0 & 0 & 1 & 0 & 0 & 1 & 0 & 0 & 0 & 0 & 1 & 0 \\
\hline Or Fabian & 1 & 0 & 0 & 1 & 0 & 0 & 1 & 0 & 0 & 1 & 0 & 0 & 0 & 0 & 1 & 0 \\
\hline Green Tango & 1 & 0 & 1 & 0 & 0 & 1 & 0 & 1 & 0 & 0 & 0 & 0 & 1 & 0 & 0 & 0 \\
\hline Kenari & 1 & 0 & 0 & 1 & 0 & 1 & 0 & 1 & 0 & 0 & 0 & 0 & 1 & 0 & 0 & 0 \\
\hline Pondoh & 0 & 1 & 0 & 1 & 0 & 0 & 1 & 1 & 0 & 0 & 0 & 0 & 1 & 0 & 0 & 0 \\
\hline Fullness & 0 & 1 & 0 & 1 & 0 & 0 & 1 & 0 & 1 & 0 & 0 & 0 & 1 & 0 & 0 & 0 \\
\hline Ratih Ungu & 1 & 0 & 0 & 1 & 0 & 0 & 1 & 0 & 0 & 0 & 1 & 0 & 0 & 0 & 1 & 0 \\
\hline Kera Putih & 0 & 1 & 0 & 1 & 0 & 0 & 1 & 0 & 1 & 0 & 0 & 0 & 0 & 1 & 0 & 0 \\
\hline Mustang & 0 & 1 & 1 & 0 & 0 & 0 & 1 & 0 & 0 & 1 & 0 & 0 & 0 & 1 & 0 & 0 \\
\hline Bungo & 0 & 1 & 0 & 1 & 0 & 0 & 1 & 0 & 0 & 1 & 0 & 0 & 0 & 0 & 1 & 0 \\
\hline Or Valeria & 0 & 1 & 1 & 0 & 0 & 0 & 1 & 0 & 0 & 1 & 0 & 0 & 0 & 1 & 0 & 0 \\
\hline Lezata & 0 & 1 & 0 & 1 & 0 & 0 & 1 & 0 & 0 & 1 & 0 & 0 & 0 & 0 & 1 & 0 \\
\hline B-27 & 0 & 1 & 1 & 0 & 0 & 0 & 1 & 0 & 0 & 1 & 0 & 0 & 0 & 1 & 0 & 0 \\
\hline Fortuna & 0 & 1 & 0 & 1 & 0 & 0 & 1 & 0 & 0 & 1 & 0 & 0 & 0 & 0 & 1 & 0 \\
\hline Ratih Hijau & 0 & 1 & 1 & 0 & 0 & 0 & 1 & 0 & 0 & 1 & 0 & 0 & 0 & 0 & 1 & 0 \\
\hline B-19 & 0 & 1 & 0 & 1 & 0 & 0 & 1 & 0 & 0 & 1 & 0 & 0 & 0 & 0 & 1 & 0 \\
\hline Or Planet Hijau & 1 & 0 & 1 & 0 & 0 & 1 & 0 & 1 & 0 & 0 & 0 & 0 & 1 & 0 & 0 & 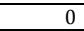 \\
\hline Gelatik & 1 & 0 & 1 & 0 & 0 & 1 & 0 & 1 & 0 & 0 & 0 & 0 & 1 & 0 & 0 & 0 \\
\hline
\end{tabular}

\begin{tabular}{|c|c|c|c|c|c|c|c|c|c|c|c|c|c|c|c|c|}
\hline VARIETAS & $\mathrm{X} 22 \mathrm{~A}$ & $\mathrm{X} 22 \mathrm{~B}$ & $\mathrm{X} 22 \mathrm{C}$ & $\mathrm{X} 22 \mathrm{D}$ & $\mathrm{X} 22 \mathrm{E}$ & $\mathrm{X} 22 \mathrm{~F}$ & $\mathrm{X} 22 \mathrm{G}$ & $\mathrm{X} 25 \mathrm{~A}$ & $\mathrm{X} 25 \mathrm{~B}$ & $\mathrm{X} 25 \mathrm{C}$ & $\mathrm{X} 25 \mathrm{D}$ & $\mathrm{X} 29 \mathrm{~A}$ & $\mathrm{X} 29 \mathrm{~B}$ & $\mathrm{X} 32 \mathrm{~A}$ & X32B & $\mathrm{X} 32 \mathrm{C}$ \\
\hline Antaboga-1 & 0 & 0 & 0 & 0 & 0 & 0 & 1 & 0 & 0 & 1 & 0 & 1 & 0 & 1 & 0 & 0 \\
\hline lanang jagad & 0 & 0 & 0 & 0 & 0 & 0 & 1 & 0 & 0 & 1 & 0 & 1 & 0 & 1 & 0 & 0 \\
\hline Texas & 0 & 0 & 0 & 0 & 0 & 0 & 1 & 0 & 0 & 1 & 0 & 1 & 0 & 1 & 0 & 0 \\
\hline Bimbi & 0 & 0 & 0 & 0 & 0 & 0 & 1 & 0 & 0 & 1 & 0 & 1 & 0 & 1 & 0 & 0 \\
\hline Rami & 0 & 0 & 0 & 0 & 0 & 0 & 1 & 0 & 0 & 1 & 0 & 1 & 0 & 1 & 0 & 0 \\
\hline B-47 & 0 & 0 & 1 & 0 & 0 & 0 & 0 & 0 & 0 & 0 & 1 & 0 & 1 & 1 & 0 & 0 \\
\hline Hijo & 0 & 0 & 0 & 1 & 0 & 0 & 0 & 0 & 1 & 0 & 0 & 1 & 0 & 0 & 0 & 1 \\
\hline Hape & 0 & 0 & 0 & 0 & 0 & 0 & 1 & 0 & 1 & 0 & 0 & 1 & 0 & 1 & 0 & 0 \\
\hline Patriot & 0 & 0 & 0 & 0 & 0 & 0 & 1 & 0 & 1 & 0 & 0 & 1 & 0 & 1 & 0 & 0 \\
\hline Or Fabian & 0 & 0 & 0 & 0 & 0 & 0 & 1 & 0 & 1 & 0 & 0 & 1 & 0 & 1 & 0 & 0 \\
\hline Green Tango & 0 & 1 & 0 & 0 & 0 & 0 & 0 & 0 & 1 & 0 & 0 & 0 & 1 & 1 & 0 & 0 \\
\hline Kenari & 1 & 0 & 0 & 0 & 0 & 0 & 0 & 0 & 1 & 0 & 0 & 0 & 1 & 1 & 0 & 0 \\
\hline Pondoh & 1 & 0 & 0 & 0 & 0 & 0 & 0 & 0 & 1 & 0 & 0 & 0 & 1 & 1 & 0 & 0 \\
\hline Fullness & 0 & 1 & 0 & 0 & 0 & 0 & 0 & 0 & 0 & 1 & 0 & 1 & 0 & 1 & 0 & 0 \\
\hline Ratih Ungu & 0 & 0 & 0 & 0 & 0 & 0 & 1 & 0 & 0 & 1 & 0 & 1 & 0 & 1 & 0 & 0 \\
\hline Kera Putih & 0 & 0 & 0 & 0 & 0 & 0 & 1 & 0 & 0 & 1 & 0 & 1 & 0 & 1 & 0 & 0 \\
\hline Mustang & 0 & 0 & 0 & 0 & 0 & 0 & 1 & 0 & 0 & 1 & 0 & 1 & 0 & 1 & 0 & 0 \\
\hline Bungo & 0 & 0 & 0 & 0 & 0 & 0 & 1 & 0 & 0 & 1 & 0 & 1 & 0 & 1 & 0 & 0 \\
\hline Or Valeria & 0 & 0 & 0 & 0 & 0 & 0 & 1 & 0 & 0 & 1 & 0 & 1 & 0 & 1 & 0 & 0 \\
\hline Lezata & 0 & 0 & 0 & 0 & 0 & 0 & 1 & 0 & 0 & 1 & 0 & 1 & 0 & 1 & 0 & 0 \\
\hline B-27 & 0 & 0 & 0 & 0 & 0 & 0 & 1 & 0 & 0 & 1 & 0 & 1 & 0 & 1 & 0 & 0 \\
\hline Fortuna & 0 & 0 & 0 & 0 & 0 & 0 & 1 & 0 & 1 & 0 & 0 & 1 & 0 & 1 & 0 & 0 \\
\hline Ratih Hijau & 0 & 0 & 0 & 0 & 0 & 0 & 1 & 0 & 1 & 0 & 0 & 1 & 0 & 1 & 0 & 0 \\
\hline B-19 & 0 & 0 & 0 & 0 & 0 & 0 & 1 & 0 & 0 & 1 & 0 & 1 & 0 & 1 & 0 & 0 \\
\hline Or Planet Hijau & 1 & 0 & 0 & 0 & 0 & 0 & 0 & 0 & 1 & 0 & 0 & 0 & 1 & 0 & 1 & 0 \\
\hline Gelatik & 1 & 0 & 0 & 0 & 0 & 0 & 0 & 0 & 1 & 0 & 0 & 0 & 1 & 0 & 1 & 0 \\
\hline
\end{tabular}

\begin{tabular}{|c|c|c|c|c|c|c|c|c|c|c|c|c|c|c|c|}
\hline VARIETAS & X32E & $\mathrm{X} 34 \mathrm{~A}$ & $\mathrm{X} 34 \mathrm{~A}^{\mathrm{c}}$ & $\mathrm{X} 38 \mathrm{~A}$ & $\mathrm{X}^{2} 3 \mathrm{~A}^{\mathrm{c}}$ & $\mathrm{X} 42 \mathrm{~A}$ & $\mathrm{X} 42 \mathrm{~B}$ & $\mathrm{X} 42 \mathrm{C}$ & $\mathrm{X} 42 \mathrm{D}$ & $\mathrm{X} 42 \mathrm{E}$ & $\mathrm{X} 42 \mathrm{~A}$ & $\mathrm{X} 42 \mathrm{~B}$ & $\mathrm{X} 44 \mathrm{~A}$ & $\mathrm{X} 44 \mathrm{~B}$ & $\mathrm{X} 44 \mathrm{C}$ \\
\hline Antaboga-1 & 0 & 0 & 1 & 0 & 1 & 0 & 0 & 1 & 0 & 0 & 0 & 1 & 1 & 0 & 0 \\
\hline lanang jagad & 0 & 0 & 1 & 0 & 1 & 0 & 0 & 1 & 0 & 0 & 0 & 1 & 0 & 1 & 0 \\
\hline Texas & 0 & 0 & 1 & 0 & 1 & 0 & 1 & 0 & 0 & 0 & 0 & 1 & 0 & 1 & 0 \\
\hline Bimbi & 0 & 0 & 1 & 0 & 1 & 0 & 1 & 0 & 0 & 0 & 1 & 0 & 1 & 0 & 0 \\
\hline Rami & 0 & 0 & 1 & 0 & 1 & 0 & 0 & 1 & 0 & 0 & 1 & 0 & 0 & 1 & 0 \\
\hline B-47 & 0 & 1 & 0 & 1 & 0 & 1 & 0 & 0 & 0 & 0 & 1 & 0 & 0 & 0 & 1 \\
\hline Hijo & 0 & 1 & 0 & 0 & 1 & 0 & 0 & 0 & 0 & 1 & 0 & 1 & 0 & 0 & 1 \\
\hline Hape & 0 & 1 & 0 & 0 & 1 & 0 & 0 & 1 & 0 & 0 & 0 & 1 & 0 & 1 & 0 \\
\hline Patriot & 0 & 1 & 0 & 0 & 1 & 0 & 0 & 1 & 0 & 0 & 0 & 1 & 0 & 0 & 1 \\
\hline Or Fabian & 0 & 1 & 0 & 0 & 1 & 0 & 0 & 1 & 0 & 0 & 0 & 1 & 0 & 1 & 0 \\
\hline Green Tango & 0 & 1 & 0 & 1 & 0 & 0 & 1 & 0 & 0 & 0 & 0 & 1 & 1 & 0 & 0 \\
\hline Kenari & 0 & 1 & 0 & 1 & 0 & 0 & 0 & 1 & 0 & 0 & 0 & 1 & 1 & 0 & 0 \\
\hline Pondoh & 0 & 1 & 0 & 0 & 1 & 0 & 0 & 1 & 0 & 0 & 0 & 1 & 0 & 0 & 1 \\
\hline Fullness & 0 & 0 & 1 & 0 & 1 & 0 & 0 & 0 & 1 & 0 & 0 & 1 & 1 & 0 & 0 \\
\hline Ratih Ungu & 0 & 0 & 1 & 0 & 1 & 0 & 0 & 0 & 1 & 0 & 0 & 1 & 0 & 1 & 0 \\
\hline Kera Putih & 0 & 0 & 1 & 0 & 1 & 0 & 1 & 0 & 0 & 0 & 0 & 1 & 0 & 1 & 0 \\
\hline Mustang & 0 & 0 & 1 & 0 & 1 & 0 & 1 & 0 & 0 & 0 & 1 & 0 & 0 & 1 & 0 \\
\hline Bungo & 0 & 0 & 1 & 0 & 1 & 0 & 1 & 0 & 0 & 0 & 0 & 1 & 0 & 1 & 0 \\
\hline Or Valeria & 0 & 0 & 1 & 0 & 1 & 1 & 0 & 0 & 0 & 0 & 1 & 0 & 0 & 1 & 0 \\
\hline Lezata & 0 & 0 & 1 & 0 & 1 & 0 & 1 & 0 & 0 & 0 & 0 & 1 & 0 & 1 & 0 \\
\hline $\mathrm{B}-27$ & 0 & 0 & 1 & 0 & 1 & 1 & 0 & 0 & 0 & 0 & 1 & 0 & 0 & 1 & 0 \\
\hline Fortuna & 0 & 1 & 0 & 0 & 1 & 0 & 1 & 0 & 0 & 0 & 0 & 1 & 0 & 1 & 0 \\
\hline Ratih Hijau & 0 & 1 & 0 & 0 & 1 & 0 & 0 & 1 & 0 & 0 & 0 & 1 & 0 & 1 & 0 \\
\hline B-19 & 0 & 0 & 1 & 0 & 1 & 0 & 1 & 0 & 0 & 0 & 1 & 0 & 0 & 1 & 0 \\
\hline Or Planet Hijau & 0 & 1 & 0 & 1 & 0 & 0 & 0 & 1 & 0 & 0 & 0 & 1 & 0 & 1 & 0 \\
\hline Gelatik & 0 & 1 & 0 & 1 & 0 & 0 & 1 & 0 & 0 & 0 & 0 & 1 & 1 & 0 & 0 \\
\hline
\end{tabular}


Lampiran 3. Matriks Cross Section 26 Klaster

\begin{tabular}{|c|c|c|c|c|c|c|c|}
\hline Varietas & $\begin{array}{l}\text { Ada Warna } \\
\text { Antosianin }\end{array}$ & $\begin{array}{c}\text { Tipe Tumbuh } \\
\text { Tegak } \\
\end{array}$ & $\begin{array}{c}\text { Ada Intensitas } \\
\text { Antosianin }\end{array}$ & $\begin{array}{c}\text { Panjang Buah } \\
\text { Sangat Pendek }\end{array}$ & $\begin{array}{l}\text { Ratio Panjang Per } \\
\text { Diameter Sedang }\end{array}$ & $\begin{array}{c}\text { Bentuk Umum } \\
\text { Buah Bundar }\end{array}$ & $\begin{array}{c}\text { Bentuk Umum } \\
\text { Buah Blat Telur }\end{array}$ \\
\hline Or Plane & 0.9971 & 0.7479 & 0.9962 & 0.9964 & 0.0025 & 0.7472 & 0.2491 \\
\hline $\begin{array}{l}\text { Gelatik } \\
\end{array}$ & 0.9971 & 0.7479 & 0.9962 & 0.9964 & 0.0025 & 0.7472 & 0.2491 \\
\hline $\begin{array}{l}\text { Green } \mathrm{Ta} \\
\end{array}$ & 0.9971 & 0.7479 & 0.9962 & 0.9964 & 0.0025 & 0.7472 & 0.2491 \\
\hline Kenari & 0.9971 & 0.7479 & 0.9962 & 0.9964 & 0.0025 & 0.7472 & 0.2491 \\
\hline B19 & 0.0019 & 0.0015 & 0.0009 & 0.0011 & 0.9977 & 0.0008 & 0.0003 \\
\hline Bungo & 0.0019 & 0.0015 & 0.0009 & 0.0011 & 0.9977 & 0.0008 & 0.0003 \\
\hline Lezata & 0.0019 & 0.0015 & 0.0009 & 0.0011 & 0.9977 & 0.0008 & 0.0003 \\
\hline Texas & 0.0019 & 0.0015 & 0.0009 & 0.0011 & 0.9977 & 0.0008 & 0.0003 \\
\hline B27 & 0.0025 & 0.9957 & 0.0013 & 0.0015 & 0.0033 & 0.001 & 0.0004 \\
\hline Mustang & 0.0025 & 0.9957 & 0.0013 & 0.0015 & 0.0033 & 0.001 & 0.0004 \\
\hline Or Valer & 0.0025 & 0.9957 & 0.0013 & 0.0015 & 0.0033 & 0.001 & 0.0004 \\
\hline Rami & 0.0025 & 0.002 & 0.0013 & 0.0015 & 0.6657 & 0.001 & 0.0004 \\
\hline Antaboga & 0.0025 & 0.002 & 0.0013 & 0.0015 & 0.6657 & 0.001 & 0.0004 \\
\hline Lanang J & 0.0025 & 0.002 & 0.0013 & 0.0015 & 0.6657 & 0.001 & 0.0004 \\
\hline Hape & 0.9943 & 0.003 & 0.0019 & 0.0023 & 0.9954 & 0.0015 & 0.0006 \\
\hline Or Fabia & 0.9943 & 0.003 & 0.0019 & 0.0023 & 0.9954 & 0.0015 & 0.0006 \\
\hline Ratih Un & 0.0038 & 0.4983 & 0.0019 & 0.0023 & 0.9954 & 0.0015 & 0.0006 \\
\hline Patriot & 0.6629 & 0.004 & 0.0025 & 0.003 & 0.665 & 0.002 & 0.0007 \\
\hline B47 & 0.9887 & 0.006 & 0.0037 & 0.0045 & 0.9909 & 0.003 & 0.0011 \\
\hline Hijo & 0.9887 & 0.006 & 0.9849 & 0.9856 & 0.0098 & 0.003 & 0.0011 \\
\hline Pondoh & 0.9887 & 0.006 & 0.0037 & 0.0045 & 0.0098 & 0.003 & 0.0011 \\
\hline Bimbi & 0.0075 & 0.006 & 0.0037 & 0.9856 & 0.0098 & 0.9841 & 0.0011 \\
\hline Ratih $\mathrm{Hi}$ & 0.0075 & 0.9871 & 0.0037 & 0.0045 & 0.9909 & 0.003 & 0.0011 \\
\hline Fortuna & 0.0148 & 0.0118 & 0.0073 & 0.0088 & 0.0193 & 0.0058 & 0.9651 \\
\hline Kera Put & 0.3989 & 0.3183 & 0.1977 & 0.2378 & 0.5202 & 0.1577 & 0.0584 \\
\hline $\begin{array}{l}\text { Fullness } \\
\end{array}$ & 0.3989 & 0.3183 & 0.1977 & 0.2378 & 0.5202 & 0.1577 & 0.0584 \\
\hline
\end{tabular}

\begin{tabular}{|l|c|c|c|c|c|c|c|}
\hline Varietas & $\begin{array}{c}\text { Bentuk Umum } \\
\text { Buah Bentuk Pir }\end{array}$ & $\begin{array}{c}\text { Bentuk Umum } \\
\text { Buah Silindris }\end{array}$ & $\begin{array}{c}\text { Warna Buah Masak } \\
\text { Panen Hijau }\end{array}$ & $\begin{array}{c}\text { Warna Buah Masak } \\
\text { Panen Ungu }\end{array}$ & $\begin{array}{c}\text { Ada Garis } \\
\text { Buah }\end{array}$ & $\begin{array}{c}\text { Tulang Buah } \\
\text { Lemah }\end{array}$ & $\begin{array}{c}\text { Tulang Buah } \\
\text { Sedang }\end{array}$ \\
\hline Or Plane & 0.0002 & 0.0034 & 0.9973 & 0.0025 & 0.0036 & 0.498 & 0.0002 \\
\hline Gelatik & 0.0002 & 0.0034 & 0.9973 & 0.0025 & 0.0036 & 0.498 & 0.0002 \\
\hline Green Ta & 0.0002 & 0.0034 & 0.9973 & 0.0025 & 0.0036 & 0.498 & 0.0002 \\
\hline Kenari & 0.0002 & 0.0034 & 0.9973 & 0.0025 & 0.0036 & 0.498 & 0.0002 \\
\hline B19 & 0.0002 & 0.9986 & 0.0021 & 0.9977 & 0.9989 & 0.0004 & 0.0002 \\
\hline Bungo & 0.0002 & 0.9986 & 0.0021 & 0.9977 & 0.9989 & 0.0004 & 0.0002 \\
\hline Lezata & 0.0002 & 0.9986 & 0.0021 & 0.9977 & 0.9989 & 0.0004 & 0.0002 \\
\hline Texas & 0.0002 & 0.9986 & 0.0021 & 0.9977 & 0.9989 & 0.0004 & 0.0002 \\
\hline B27 & 0.0002 & 0.9981 & 0.0028 & 0.9969 & 0.9985 & 0.0005 & 0.0002 \\
\hline Mustang & 0.0002 & 0.9981 & 0.0028 & 0.9969 & 0.9985 & 0.0005 & 0.0002 \\
\hline Or Valer & 0.0002 & 0.9981 & 0.0028 & 0.9969 & 0.9985 & 0.0005 & 0.0002 \\
\hline Rami & 0.0002 & 0.9981 & 0.0028 & 0.9969 & 0.9985 & 0.0005 & 0.0002 \\
\hline Antaboga & 0.0002 & 0.9981 & 0.0028 & 0.9969 & 0.9985 & 0.0005 & 0.0002 \\
\hline Lanang J & 0.0002 & 0.9981 & 0.0028 & 0.9969 & 0.9985 & 0.0005 & 0.0002 \\
\hline Hape & 0.0004 & 0.9972 & 0.9947 & 0.005 & 0.9977 & 0.0007 & 0.0004 \\
\hline Or Fabia & 0.0004 & 0.9972 & 0.9947 & 0.005 & 0.9977 & 0.0007 & 0.0004 \\
\hline Ratih Un & 0.0004 & 0.9972 & 0.9947 & 0.005 & 0.9977 & 0.0007 & 0.0004 \\
\hline Patriot & 0.0005 & 0.9962 & 0.0056 & 0.9939 & 0.997 & 0.001 & 0.0005 \\
\hline B47 & 0.0007 & 0.9944 & 0.9894 & 0.0098 & 0.9955 & 0.0015 & 0.0007 \\
\hline Hijo & 0.0007 & 0.0132 & 0.0083 & 0.0098 & 0.0144 & 0.0015 & 0.0007 \\
\hline Pondoh & 0.9819 & 0.0132 & 0.9894 & 0.0098 & 0.9955 & 0.0015 & 0.9819 \\
\hline Bimbi & 0.0007 & 0.0132 & 0.9894 & 0.0098 & 0.0144 & 0.0015 & 0.0007 \\
\hline Ratih Hi & 0.0007 & 0.9944 & 0.0083 & 0.9909 & 0.9955 & 0.0015 & 0.0007 \\
\hline Fortuna & 0.0014 & 0.026 & 0.0163 & 0.9822 & 0.9912 & 0.0029 & 0.0014 \\
\hline Kera Put & 0.0388 & 0.7019 & 0.4393 & 0.5203 & 0.7622 & 0.0782 & 0.0388 \\
\hline Fullness & 0.0388 & 0.7019 & 0.4393 & 0.5203 & 0.7622 & 0.0782 & 0.0388 \\
\hline
\end{tabular}

\begin{tabular}{|c|c|c|c|c|c|c|}
\hline Varietas & $\begin{array}{c}\text { Ada Antosianin Bawah } \\
\text { Kelopak Bunga }\end{array}$ & $\begin{array}{c}\text { Intensitas Antosianin Kelopak } \\
\text { Bunga Sangat Lemah }\end{array}$ & $\begin{array}{c}\text { Kerutan Kelopak } \\
\text { Bunga Sedang }\end{array}$ & $\begin{array}{c}\text { Kerutan Kelopak } \\
\text { Bunga Sangat Kuat }\end{array}$ & $\begin{array}{c}\text { Waktu Mulai } \\
\text { Pembungaan Sedang }\end{array}$ & $\begin{array}{c}\text { Waktu Mulai } \\
\text { Pembungaan Akhir }\end{array}$ \\
\hline Gelatik & 0.9975 & 0.9962 & 0.4995 & 0.0002 & 0.2518 & 0.0008 \\
\hline Green Ta & 0.9975 & 0.9962 & 0.4995 & 0.0002 & 0.2518 & 0.0008 \\
\hline B19 & 0.0023 & 0.0009 & 0.0019 & 0.0002 & 0.9982 & 0.0008 \\
\hline Bungo & 0.0023 & 0.0009 & 0.0019 & 0.0002 & 0.9982 & 0.0008 \\
\hline Lezata & 0.0023 & 0.0009 & 0.0019 & 0.0002 & 0.9982 & 0.0008 \\
\hline Mustang & 0.0031 & 0.0013 & 0.0025 & 0.0002 & 0.9976 & 0.001 \\
\hline Or Valer & 0.0031 & 0.0013 & 0.0025 & 0.0002 & 0.9976 & 0.001 \\
\hline Rami & 0.0031 & 0.0013 & 0.9962 & 0.0002 & 0.6664 & 0.001 \\
\hline Antaboga & 0.0031 & 0.0013 & 0.9962 & 0.0002 & 0.6664 & 0.001 \\
\hline Lanang J & 0.0031 & 0.0013 & 0.9962 & 0.0002 & 0.6664 & 0.001 \\
\hline Hape & 0.995 & 0.0019 & 0.9943 & 0.0004 & 0.9964 & 0.0015 \\
\hline Or Fabia & 0.995 & 0.0019 & 0.9943 & 0.0004 & 0.9964 & 0.0015 \\
\hline Pondoh & 0.9902 & 0.0037 & 0.0075 & 0.9819 & 0.0117 & 0.9841 \\
\hline Bimbi & 0.9902 & 0.0037 & 0.9887 & 0.0007 & 0.0117 & 0.9841 \\
\hline Ratih $\mathrm{Hi}$ & 0.0091 & 0.0037 & 0.0075 & 0.0007 & 0.0117 & 0.003 \\
\hline Fortuna & 0.0178 & 0.0073 & 0.0148 & 0.0014 & 0.023 & 0.0058 \\
\hline Kera Put & 0.4797 & 0.1977 & 0.399 & 0.0388 & 0.6213 & 0.1577 \\
\hline Fullness & 0.4797 & 0.1977 & 0.399 & 0.0388 & 0.6213 & 0.1577 \\
\hline
\end{tabular}

